\title{
The Importance of Trust
}

\author{
Laurence Thomas* \\ Political Science and Philosophy, Syracuse University, USA
}

Submission: July 12, 2018; Published: July 20, 2018

*Corresponding author: Laurence Thomas, Political Science and Philosophy, Syracuse University, USA, Tel: (315) 443-5824;

Email: lthomas@syr.edu

Keywords: Trust; Human beings; Gamma; Goodwill; Siblings; Tremendous love; Drowning; Unequivocally; Trustworthy; Technology; Society; Country; Importance

\section{Opinion}

To state the obvious, the sentiment of love plays an extremely important role among human beings. Throughout the world, there is romantic love and there is parental love and there is the love between siblings and there is the is love between friends. Of course, one can ask whether one form of love is more significant than the other forms. Alas, a quite significant truth is that if any one of the forms of love mentioned were completely absent among human beings, then it would be unequivocally true that owing to the absence of the form of love in question, there would clearly be a quite substantial difference in the behavior of human beings that would reflect the absence of that form of love.

Regardless of the type of love, the very nature of love at its very best is the genuine affirmation that is clearly a majestic display of that love. And while it is certainly the case that a person can occasionally be unclear that a form of behavior was a display of love, an incontrovertible truth is that by-and-large the display of genuine love is unequivocally obvious. The connection between love and trust is obvious. For goodwill is unequivocally one of the most significant features of love. And trust is rightly the response to the goodwill that is so clearly occasioned by a person's love. Indeed, the very idea that person Gamma has tremendous love towards an individual who without doubt is a morally decent person but, yet person Gamma displays no goodwill towards that person is utterly incoherent.

Of course, it goes without saying that an individual may be able to perform one kind or form of goodwill but not another. An obvious example of the point just made is the following. It can be that person Gamma is clearly in the position to help Beta financially. However, Gamma simply cannot swim. So, if Gamma sees Beta drowning, it will not make any sense at all for Gamma to jump into the river or pool to save Beta, since what is ever so likely to happen is that person Gamma will also start drowning.
There is no denying the importance of trust. Alas, from the fact that a person is trustworthy, and so would do no wrong, it does not follow at all that such a person has the wherewithal to help a person who is drowning.

There are simpler examples of the point made in the preceding paragraph. Jesse may be visiting foreign country Alpha. Alas, everyone who sees him wrongly thinks that he was born in that country and grew up in that country. Hence, he is routinely approached by foreigners for directions. In this case, though, the minute Jesse starts speaking, it will be manifestly clear that Jesse is not capable pf speaking the language spoken in country Alpha. Hence, those who approached Jesse apologize for doing so and move one.

To conclude, the reality is that we must sharply distinguish between (a) negative trustworthiness (and thus not harming another) and (b) positive trustworthiness (and thus offering assistance to another who is in need of assistance). The very foundation of a just society is negative trustworthiness. And while there are forms of negative trustworthiness that are within the reach countless many individuals (such as call the police when someone has fallen), the reality is that there are clearly forms of negative harm that are clearly beyond the ability of the average person not be able to offer assistance.

Alas, thanks to the development of technology, a quite significant truth is that while a person may not be able to offer assistance to a person who has suffered tremendous harm, the reality is that nowadays (thanks to cellphones) the average person can report the substantial harm to police officials. And the very reality that the vast majority of the members of a society are able so behave is an incontrovertible affirmation of the moral good that exists in that society that is anchored the development of what may refer to as personal technology. 
Without a doubt, there morally bad things that have been occasioned by personal technology. And that reality speaks to the importance of understanding and defining the parameters of trust in any society in which technology has come to have a fundamental place in the life of individuals. If basic trust takes a horrific diminution on account of the increasing development of technology, then there will be an ever so painful respect in which technology will have done human beings more harm than good.

This work is licensed under Creative Commons Attribution 4.0 License DOI: 10.19080/GJAA.2018.05.555667

\section{Your next submission with Juniper Publishers will reach you the below assets}

- Quality Editorial service

- Swift Peer Review

- Reprints availability

- E-prints Service

- Manuscript Podcast for convenient understanding

- Global attainment for your research

- Manuscript accessibility in different formats

( Pdf, E-pub, Full Text, Audio)

- Unceasing customer service

Track the below URL for one-step submission https://juniperpublishers.com/online-submission.php 